\title{
A new locus for autosomal recessive complicated hereditary spastic paraplegia (SPG26) maps to chromosome $12 \mathrm{p} 11.1-12 \mathrm{q} 14$
}

\author{
P A Wilkinson, M A Simpson, L Bastaki, H Patel, J A Reed, K Kalidas, E Samilchuk, R Khan, \\ T T Warner, A H Crosby
}

$\mathrm{T}$ he term hereditary spastic paraplegia (HSP) is used to describe a group of clinically and genetically heterogeneous disorders in which the defining clinical feature is progressive spasticity and weakness of the lower limbs. The phenotype is traditionally classified as "pure" when symptoms and signs are generally confined to those of a progressive spastic paraparesis, or "complicated" when associated with additional neurological or other clinical features. ${ }^{1}$ Inheritance may be autosomal dominant, autosomal recessive, or rarely $\mathrm{X}$ linked. Overall autosomal dominant inheritance is most commonly associated with pure forms of the disease, whereas autosomal recessive HSP shows greater phenotypic variability, including several well defined syndromes. ${ }^{23}$

To date nine autosomal recessive HSP loci have been identified and causative mutations found in three genes: SPG7 (paraplegin), SPG20 (spartin), and SPG21 (maspardin). SPG7 encodes paraplegin, a mitochondrial protein, which is a member of the AAA protein superfamily (ATPase associated with diverse cellular activities) and is homologous to a number of yeast mitochondrial metalloproteases. ${ }^{4}$ SPG7 mutations may result in either pure or complicated HSP phenotypes. ${ }^{45}$ Muscle biopsy analysis of patients with SPG7 mutations may show histological evidence of mitochondrial dysfunction $^{4}{ }^{6}$ and recently biochemical studies have shown specific defects in mitochondrial respiratory chain function. ${ }^{5}$

Mutations in the SPG20 and SPG21 genes have so far only been identified in the Old Order Amish population in association with well characterised complicated HSP phenotypes. $^{8}{ }^{9}$ Spartin, the protein product of SPG20 mutated in Troyer syndrome, contains a MIT domain that is found almost exclusively in molecules thought to play a role in subcellular trafficking. ${ }^{810}$ Only one study has so far been published relating to the function of maspardin-the protein product of the SPG21 gene mutated in Mast syndrome. This suggests co-localisation with transportation vesicles and implies a role in protein transportation or sorting..$^{11}$

In the current study we have ascertained a large consanguineous family comprising five affected and seven unaffected siblings in which the parents were first cousins of Bedouin ancestry. ${ }^{12}$ A uniform early onset of disease at between seven and eight years of age was noted. At the time of examination all affected individuals had signs of a progressive spastic paraparesis with dysarthria and distal amyotrophy in both upper and lower limbs. The three eldest affected subjects were also felt to have a degree of intellectual impairment (table 1) with reduced IQ, although it is unclear whether this represents progressive cognitive decline. Neurological examination of the parents and the remaining siblings was unremarkable. Routine biochemical studies and neurophysiological testing including nerve conduction

\section{Key points}

- The hereditary spastic paraplegias (HSPs) are a genetically and clinically heterogeneous group of neurodegenerative disorders.

- A genome-wide screen was carried out in a consanguineous Kuwaiti family with autosomal recessive HSP complicated by dysarthria, distal amyotrophy, and mild intellectual impairment in some affected individuals.

- This defined a single region of homozygosity cosegregating with the disease spanning $22.8 \mathrm{cM}$ of chromosome 12p11.1-12q14, flanked by markers D12S59 and D12S1676 (multipoint LOD score = 5.1).

- This HSP neuropathy represents a novel genetic entity designated SPG26.

velocities and EEG were normal. The appearances on magnetic resonance imaging were normal.

Linkage to the previously described autosomal recessive HSP loci was excluded using polymorphic microsatellite markers spanning these regions (data not shown). Genomewide linkage analysis, using parents and affected individuals only, was carried out with the ABI linkage marker set (version 2.5) with an ABI 3100 genetic analyser and Genotyper software (version 3.7).

A single region of homozygosity was identified on chromosome 12 flanked by markers D12S345 and D12S326. Marker saturation analysis demonstrated a $22.8 \mathrm{cM}$ region of homozygosity co-segregating with the disease in all affected individuals flanked by markers D12S59 and D12S1676 (fig 1). Multipoint LOD scores across the region-calculated using GENEHUNTER (version 2.1) under the assumption of equal allele frequencies and equal male and female recombination rates, with the disease modelled as an autosomal recessive trait with complete penetrance (allele frequency $10^{-4}$ ) - were significantly positive, with a maximum score of 5.1 between markers D12S1686 and D12S1702 (fig 2). A database search of the critical interval identified approximately 300 known or predicted genes including KIF5A, in which a missense mutation (A767G) has previously been reported in a family with an uncomplicated autosomal dominant form of HSP. ${ }^{13}$ Direct sequencing of all 28 exons and splice junctions of the KIF5A gene, as previously described, ${ }^{13}$ in parents and affected individuals did not reveal any pathogenic mutations.

Abbreviations: HSP, hereditary spastic paraplegia 


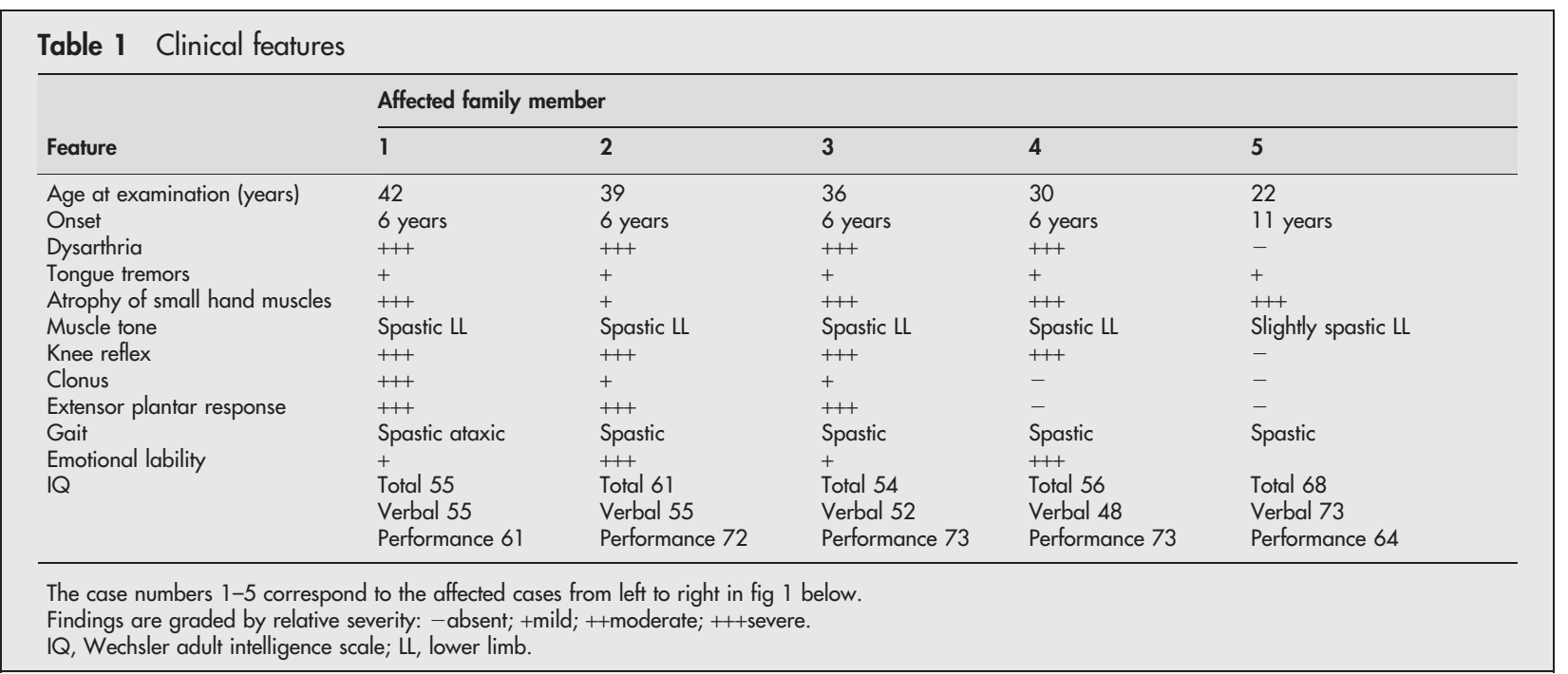

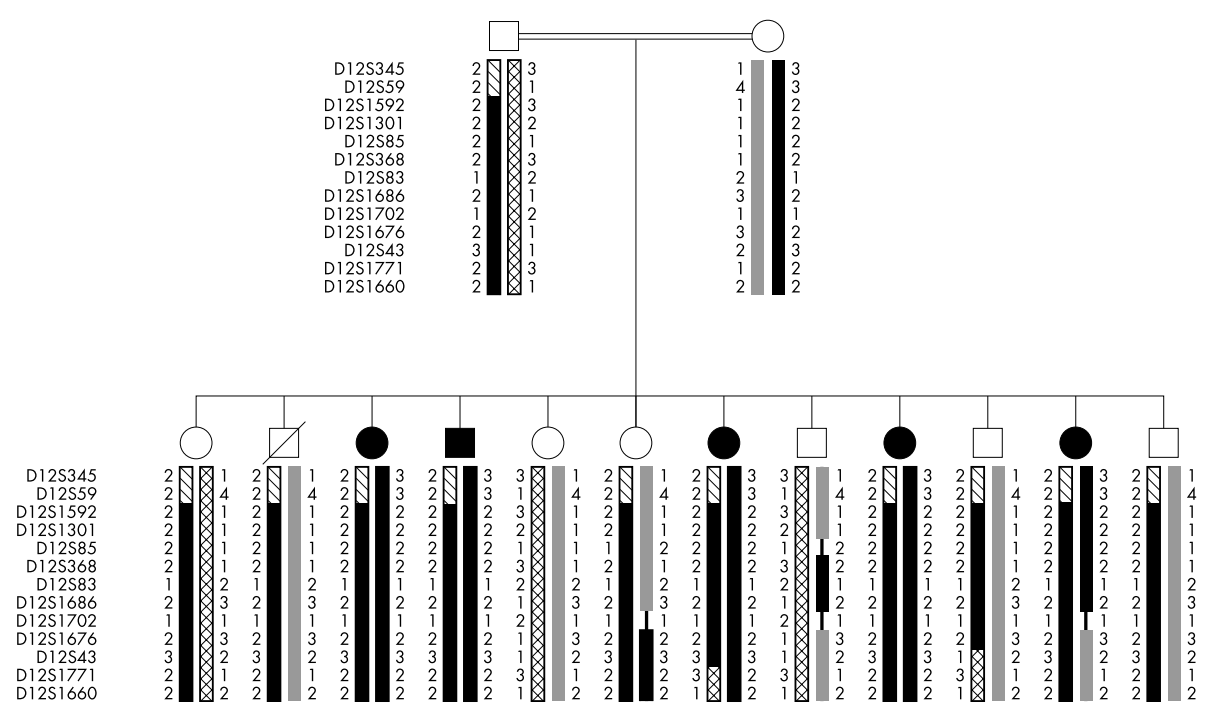

Figure 1 Pedigree of the Kuwaiti family used to map the SPG26 locus, showing haplotypes across the interval.

However, we cannot exclude the possibility of an intronic mutation or a mutation in a distant regulatory sequence.

\section{COMMENT}

Using this consanguineous Kuwaiti family we have identified a novel locus for autosomal recessive complicated HSP to a $22.8 \mathrm{cM}$ region on chromosome 12. Although this region contains the KIF5A gene, the fact that no pathogenic mutations were identified in affected individuals in any of the exons and flanking splice junctions in this pedigree is strongly supportive of a further causative gene in this region. The different mode of inheritance and different phenotype compared with that of KIF5A offers further support of this hypothesis. This study should prompt the investigation of additional autosomal recessive HSP families for linkage to this region on chromosome 12 , which may aid in the refinement of this currently large locus. Based upon the proposed functions of the genes so far identified in the various forms of HSP, various different underlying pathogenic mechanisms have been proposed, including the disrupted development of the corticospinal tracts, mitochondrial dysfunction, and defects in subcellular transportation and sorting processes. ${ }^{14-16}$ The ultimate identification of the SPG26 causative gene will further elucidate the pathogenesis

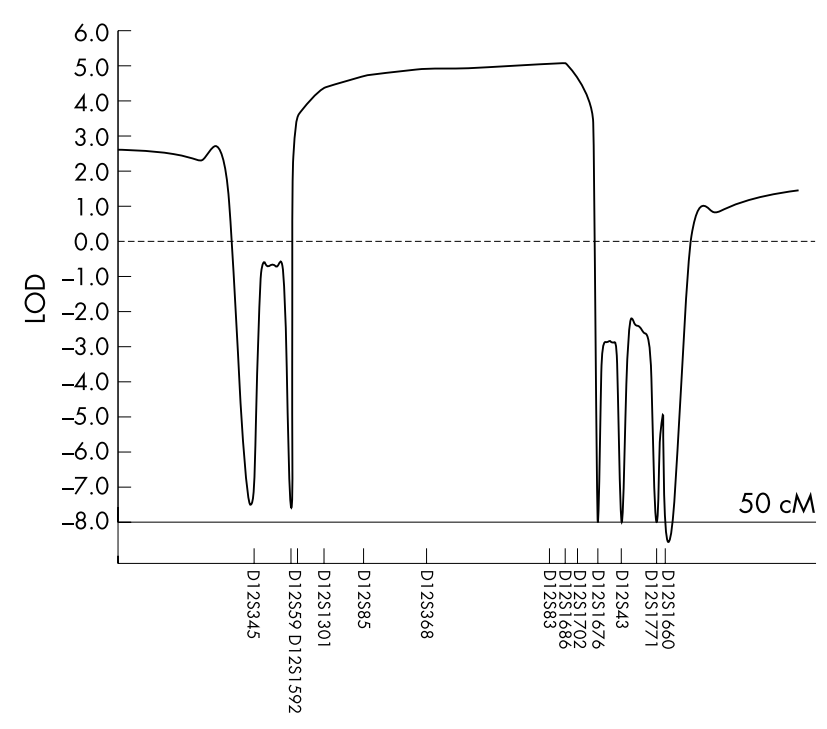

Figure 2 Multipoint LOD scores for markers situated across the SPG 26 locus, flanked by markers D12S59 and D12S1676, producing a peak score of 5.1 . 
of this form of HSP and improve our understanding of the mechanisms of neurodegeneration in this heterogeneous disease.

\section{ACKNOWLEDGEMENTS}

We are grateful to all the patients and their relatives who participated in this study. This work was supported by grants from Action Medical Research UK, the Birth Defects Foundation (UK), and The Wellcome Trust. The work was carried out within the network of the London Ideas Knowledge Park.

\section{Authors' affiliations \\ P A Wilkinson, M A Simpson, H Patel, J A Reed, K Kalidas, A H Crosby, Department of Medical Genetics, St George's Hospital Medical School, London SW17, UK \\ P A Wilkinson, T T Warner, Department of Clinical Neurosciences, Royal Free and University College Medical School, London NW3, UK L Bastaki, E Samilchuk, R Khan, Kuwait Medical Genetics Centre, Maternity Hospital, Kuwait \\ Competing interests: none declared \\ Correspondence to: Dr Andrew H Crosby, Department of Medical Genetics, St George's Hospital Medical School, Cranmer Terrace, London SW17 ORE, UK; acrosby@sghms.ac.uk}

\section{REFERENCES}

1 Harding AE. The hereditary ataxias, related disorders. Edinburgh: Churchill Livingstone, 1984.

2 Coutinho P, Barros J, Zemmouri R, Guimaraes J, Alves C, Chorao R Lourenco E, Ribeiro P, Loureiro JL, Santos JV, Hamri A, Paternotte C, Hazan J, Silva MC, Prud'homme JF, Grid D. Clinical heterogeneity of autosomal recessive spastic paraplegias: analysis of 106 patients in 46 families. Arch Neurol 1999:56:943-9.

3 Polo JM, Calleja J, Combarros O, Berciano J. Hereditary "pure" spastic paraplegia: a study of nine families. J Neurol Neurosurg Psychiatry 1993;56:175181.
4 Casari G, De Fusco M, Ciarmatori S, Zeviani M, Mora M, Fernandez P, De Michele G, Filla A, Cocozza S, Marconi R, Durr A, Fontaine B, Ballabio A. Spastic paraplegia and OXPHOS impairment caused by mutations in paraplegin, a nuclear-encoded mitochondrial metalloprotease. Cell 1998.93:973-83.

5 Wilkinson PA, Crosby AH, Turner C, Bradley U, Ginsberg L, Wood NW, Schapira AH, Warner TT. A clinical, genetic and biochemical study of SPG7 mutations in hereditary spastic paraplegia. Brain 2004; 127:973-80.

6 McDermott CJ, Dayaratne RK, Tomkins J, Lusher ME, Lindsey JC, Johnson MA, Casari G, Turnbull DM, Bushby K, Shaw PJ. Paraplegin gene analysis in hereditary spastic paraparesis (HSP) pedigrees in northeast England. Neurology 2001;56:467-71.

7 Atorino L, Silvestri L, Koppen M, Cassina L, Ballabio A, Marconi R, Langer T, Casari $G$. Loss of $m$-AAA protease in mitochondria causes complex I deficiency and increased sensitivity to oxidative stress in hereditary spastic paraplegia. J Cell Biol 2003;163:777-87.

8 Patel H, Cross H, Proukakis C, Hershberger R, Bork P, Ciccarelli FD, Patton MA, McKusick VA, Crosby AH. SPG20 is mutated in Troyer syndrome, an hereditary spastic paraplegia. Nat Genet 2002;31:347-8.

9 Simpson MA, Cross H, Proukakis C, Pryde A, Hershberger R, Chatonnet A Patton MA, Crosby AH. Maspardin is mutated in mast syndrome, a complicated form of hereditary spastic paraplegia associated with dementia. Am J Hum Genet 2003;73:1 147-56.

10 Ciccarelli FD, Proukakis C, Patel H, Cross H, Azam S, Patton MA, Bork P Crosby $\mathrm{AH}$. The identification of a conserved domain in both spartin and spastin, mutated in hereditary spastic paraplegia. Genomics 2003;81:437-41.

11 Zeitlmann L, Sirim P, Kremmer E, Kolanus W. Cloning of ACP33 as a novel intracellular ligand of CD4. J Biol Chem 2001;276:9123-32.

12 Farag TI, el-Badramany MH, al-Sharkawy S. Toyer syndrome: report of the first "non-Amish" sibship and review. Am J Med Genet 1994:53:383-5.

13 Reid E, Kloos M, Ashley-Koch A, Hughes L, Bevan S, Svenson IK, Graham FL, Gaskell PC, Dearlove A, Pericak-Vance MA, Rubinsztein DC, Marchuk DA. A kinesin heavy chain (KIF5A) mutation in hereditary spastic paraplegia (SPG10). Am J Hum Genet 2002;71:1189-94.

14 Crosby $\mathrm{AH}$, Proukakis $\mathrm{C}$. Is the transportation highway the right road for hereditary spastic paraplegia? Am J Hum Genet 2002;71:1009-16.

15 Crosby AH. Disruption of cellular transport: a common cause of neurodegeneration? Lancet Neurol 2003;2:31 1-31.

16 Reid E. Science in motion: common molecular pathological themes emerge in the hereditary spastic paraplegias. J Med Genet 2003;40:81-6. 